Original Research Paper

\title{
Potential of Hyacinth Activated Carbon in Lowering Levels of Lead Heavy Metals by Method of Atomic Absorption Spectrophotometry
}

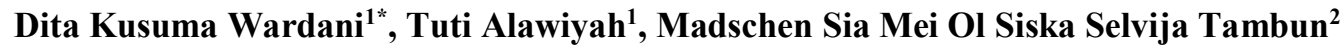 \\ ${ }^{1}$ Department of Pharmacy, Faculty of Health, Sari Mulia University. Banjarmasin, Indonesia. \\ ${ }^{2}$ Department of Industrial, Faculty of Engineering, Sari Mulia University. Banjarmasin, \\ Indonesia.
}

\section{Article History}

Received:

17.11.2021

Revised:

17.12.2021

Accepted:

20.12.2021

*Corresponding Author:

Dita Kusuma Wardani

Email:

kusumadita3@gmail.com

This is an open access article, licensed under: $\mathrm{CC}-\mathrm{BY}-\mathrm{SA}$

\begin{abstract}
The Barito River as the largest and longest river in South Kalimantan has been convicted as the most polluted river on an international level. Where one of the most commonly found compounds is the heavy metal lead $(\mathrm{Pb})$ with a high enough levels that alternatives are needed to reduce the levels of the metal. One way to reduce the levels of such heavy metals is to use activated carbon hyacinth. So the activated carbon from hyacinth is made in accordance with SII No.0258-79 and knows the effect of variations in the administration of activated carbon hyacinth at a time of 15 minutes, 30 minutes and 45 minutes in lowering the levels of lead heavy metals $(\mathrm{Pb})$. The research method used to determine the effect of variations in the administration of activated carbon hyacinth is by quantitative testing using the Atomic Absorption Spectrophotometry tool. The results showed that activated carbon hyacinth has met SII No.0258-79 with a randemen test result of $15 \%$, water content of $3 \%$, and absorption of iodine of $241.16 \mathrm{mg} /$ gram. Significant value produced 0.742 with regression value (r) 0.999 and resulted in decreased lead metal levels in the variation of 15 minutes activated carbon administration of $-0.030 \mathrm{mg} / 1$ with an absorption of $120 \%, 30$ minutes of $0.073 \mathrm{mg} / 1$ with an absorption of $48 \%$ and 45 minutes of $-0.097 \mathrm{mg} / 1$ with an absorption of $167 \%$. Hyacinth activated carbon can be used to lower the levels of lead heavy metals $(\mathrm{Pb})$ with a maximum contact time of 45 minutes by $167 \%$.
\end{abstract}

Keywords: Activated Carbon, $\mathrm{HCl}$ Activation, Hyacinth, Lead Heavy Metals. 


\section{Introduction}

South Kalimantan is one of the provinces in Indonesia that has many rivers as one of its natural resources. The longest river in South Kalimantan is the Barito River which is home to several major rivers in South Kalimantan, such as martapura river and sungai negara. The springs of the Barito River originate from the interior of Central Kalimantan and empties into the Java Sea. The Barito River has many tributaries, and since long ago the area along the river flow has been a place of settlement [1].

The findings of several researchers, the Environment Hall, the Environmental Lovers Group of River Caring Communities (MELINGAI) and the River Region Hall (BWS) II showed that there are still many communities around who use the Barito River for household activities such as bathing, drinking, to fish cultivation, especially communities in upstream areas of the river. The results of the preliminary study of Hikmah [2] on 20 people around the Barito River precisely in Pelambuan Village, West Banjarmasin found that $45 \%$ of the community uses PDAM water, $20 \%$ of the community consumes river water to drink with a mixture of PDAM water and $35 \%$ uses river water for bathing.

\section{Literature Review}

One source of pollution that is very harmful to both human health and the environment is lead waste $(\mathrm{Pb})$. Lead metal can come from industrial, household waste, unused batteries or from mining [3].

According to Sofarini et al [4] in the waters of the Barito Watershed estuary including the Kelayan River, Alalak River and Kuin River, obtained the value of lead metal found at the observation station averaged $0.002 \mathrm{mg} / 1$ to $0.17667 \mathrm{mg} / 1$, with the highest lead content found in the Kelayan River. This value is above the maximum threshold found in the waters according to Decree No.32 of 2017 on the quality of lead concentration in the waters that should not exceed $0.05 \mathrm{mg} / 1$.

This condition indicates that the waters of the Barito River are polluted by lead metal $(\mathrm{Pb})$ so alternatives are needed to reduce the levels of the metal. The dangers of lead can have an impact on damage to human organs, especially the nervous system, blood formation system, kidneys, heart and reproduction. One way to reduce the levels of heavy metals is to use activated carbon. Activated carbon is a type of adsorbent that has been used to absorb a wide variety of organic and inorganic impurities. This adsorption process offers flexibility in design and operation in many cases [5].

Hyacinth is one of the plants that can do adsorption. The ability of hyacinths to absorb is caused because it has smooth branched roots that serve as a tool to absorb chemical compounds, so that the toxicity of dissolved chemical compounds is reduced. Hyacinth can also be used as an adsorbent for heavy metals including Ni (II), $\mathrm{Cu}$ (II), Mercury (II) [6].

Based on the results of research on the large content of lead heavy metals $(\mathrm{Pb})$ in the Barito River and the effectiveness of activated carbon in lowering heavy metals, researchers want to conduct research on the Potential of Hyacinth Activated Carbon (Eichhornia crassipes) in Lowering Lead Heavy Metal $(\mathrm{Pb})$ Levels with the Atomic Absorption Spectrophotometry Method (AAS).

\section{Methodology}

The tools used in this study include 1 set of atomic absorption spectrophotometry tools, 70 mesh sizes, glass tools, ovens, kilrs, analytical balance sheets, whatman 41 paper, stopwatches, volume pipettes, drop pipettes, aluminum foil, porcelain cups, magnetic stirers.

The materials used are hyacinth plants, Barito River water, aquadest, concentrated $\mathrm{HNO}_{3}, \mathrm{NaOH}, \mathrm{KI}$ and $\mathrm{HCl}$.

The method used in this study is posttest with control design. The grouping of control group members (without activated carbon administration) and experimental groups (by administering activated carbon at 15 minutes, 30 minutes and 45 minutes) was measured using Atomic Absorption Spectrophotometry (SSA).

\subsection{Sample Preparation}

Hyacinth leaves that have been cut are dried in the sun for 7 days, then mashed using a blander. The fine hyacinth is then burned (carbonized) using a furnace at $600^{\circ} \mathrm{C}$ for 1 hour until it becomes charcoal and cooled until it reaches room temperature. Charcoal is sedated with a size 60 mesh sying. Hyacinth charcoal as much as 40 grams is contacted with a solution of $\mathrm{HCl} 1 \mathrm{M}$ as much as $500 \mathrm{ml}$ then stirred using magnetic stirrer for 10 minutes and then silenced for 24 hours. Strain using whatman 41 paper, then wash using $\mathrm{NaOH}$ and aquadest until the $\mathrm{pH}$ is neutral using a universal $\mathrm{pH}$.

Barito River water samples of $120 \mathrm{ml}$ each are included in a $250 \mathrm{ml}$ erlenmeyer then added 5-10 ml of concentrated $\mathrm{HNO}_{3}$ and homogenized with magnetic stirrer for 20 minutes, after which it is filtered using filter paper and put in a glass bottle and each labeled for the control group (without activated 
carbon administration) and treatment group (with activated carbon administration at 15 minutes, 30 minutes and 45 minutes).

\subsection{Hyacinth Activated Carbon Quality Test}

\subsubsection{Randemen Test}

Hyacinth is done to reduce water content by basking in the hot sun, then then weighed. Do dry hyacinth burning at a temperature of $600^{\circ} \mathrm{C}$ by using furnance until charcoal is produced. Soak the charcoal with an $\mathrm{HCl} 1 \mathrm{M}$ activator for 24 hours then re-neutralize it using $\mathrm{NaOH}$ and aquadest, then dry it using the oven and weigh the results. Calculate the number obtained with Eq. 1.

$$
\text { Rancemen }=\frac{B}{A} \times 100 \%
$$

where,

A $=$ Weight of the raw materials assembled (gram)

$\mathrm{B}=$ Weight of the resulting charcoal (gram)

\subsubsection{Water Content Test}

Weigh the empty cup, then insert 1 gram of activated carbon hyacinth and record the weighing results. Do the venting at a temperature of $105^{\circ} \mathrm{C}$ for approximately 1 hour and then refrigerate in a decikator. Re-weigh the cup containing activated carbon that had cooled earlier. Calculate the water content obtained with with Eq. 2.

$$
\text { Water Content }=\frac{W_{1}-W_{2}}{W_{1}-W_{c}} \times 100 \%
$$

where,

$\mathrm{W}_{1}=$ Weight of the cup and sample before drying (gram)

$\mathrm{W}_{2}=$ Weight of the cup and sample after drying (gram)

$\mathrm{W}_{0}=$ Empty cup weight (gram)

\subsubsection{Ashes Test}

Weigh the empty cup, then insert 1 gram of activated carbon hyacinth and record the weighing results. Enter the cup containing activated carbon into the furnance and burn at $750{ }^{\circ} \mathrm{C}$ for an hour. Remove the cup containing activated carbon and then refrigerate in the desikator, then weigh the result of the ash obtained. Calculate the ash level with with Eq. 3.

$$
\text { Ash Rate }=\frac{m_{1}-m_{1}}{m_{2}-m_{1}} \times 100 \%
$$

$$
\begin{aligned}
& \text { where, } \\
& \mathrm{m}_{1}=\text { Empty cup weight (gram) } \\
& \mathrm{m}_{2}=\text { Weight of the cup and sample before drying (gram) } \\
& \mathrm{m}_{3}=\text { Weight of the cup and sample after drying (gram) }
\end{aligned}
$$

\subsubsection{Iodine Absorption Test}

Soak 1 gram of activated carbon hyacinth in $25 \mathrm{ml}$ of iodine for 15 minutes then strain, Take $10 \mathrm{ml}$ of the resulting filtrate and put it in the erlenmeyer. Titration by using sodium thiosulfate until light yellow color, add 5 drops of amylase indicator and then continue titration until it produces a clear color. Calculate the absorbency of the resulting iodine with with Eq. 4.

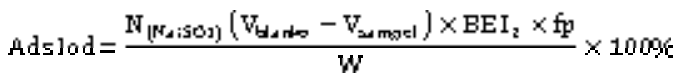

where,

$\mathrm{N}=$ Normality of solution $\mathrm{Na}_{2} \mathrm{~S}_{2} \mathrm{O}_{3}(\mathrm{ml})$

$\mathrm{V}=$ Volume of solution $\mathrm{Na}_{2} \mathrm{~S}_{2} \mathrm{O}_{3}$ required $(\mathrm{ml})$

$\mathrm{BE}=$ Equivalent weight $\mathrm{I}_{2}$ (126.91)

$\mathrm{Fp}=$ Dilution factor

$\mathrm{W}=$ Weight of activated carbon $(\mathrm{mg})$ 


\subsection{Qualitative Test}

The qualitative test is following:

1. Test with $\mathrm{HCl}$ reagent

Take a sample of $5 \mathrm{ml}$ and put in a test tube, then added with 5 drops of $\mathrm{HCl}$ and a solution will form a white precipitate if the positive sample contains lead [7].

2. Test with KI reagent

Take a sample of $5 \mathrm{ml}$ and put it in a test tube, then added with 5 drops of $\mathrm{KI}$ and a solution will form yellow deposits if the sample is positive to contain [7].

3. Test with $\mathrm{NaOH}$ reagent

Take a sample of $5 \mathrm{ml}$ and put it in a test tube, then added with 5 drops of $\mathrm{NaOH}$ and the solution will form white-colored deposits if the positive sample contains lead [8].

\subsection{Quantitative Test}

The quantitative test is following:

1. Manufacture of $\mathrm{Pb} 1000 \mathrm{ppm}$ Master Solution

$\mathrm{Pb}(\mathrm{No}) 3$ as much as $100 \mathrm{mg}$ is weighed using an analytical balance sheet then input into a 100 $\mathrm{ml}$ measuring pumpkin and then diluted by adding HNO3 $1 \mathrm{M}$ to the measuring pumpkin to the limit mark. To make $1000 \mathrm{ppm}$ of parent solution it takes $100 \mathrm{mg} / 100 \mathrm{ppm}$.

2. Manufacture of Standard Solution Raw $\mathrm{Pb} 100 \mathrm{ppm}$

Take a $1000 \mathrm{ppm}$ master solution using a pipette of $10 \mathrm{ml}$ then put it in a $100 \mathrm{ml}$ measuring pumpkin. The solution that has been taken will be diluted by adding $\mathrm{HNO}_{3} 1 \mathrm{M}$ in the measuring pumpkin to the limit mark.

3. Manufacture of Standard Solution Raw $\mathrm{Pb} 10 \mathrm{ppm}$

Take a $100 \mathrm{ppm}$ master solution using a $10 \mathrm{ml}$ pipette then put in a $100 \mathrm{ml}$ measuring pumpkin. The solution that has been taken will be diluted by adding HNO3 $1 \mathrm{M}$ in the measuring pumpkin to the limit mark.

4. Standard Series Solution Manufacturing 0.25, 0.50, 1.0 and 2.0

Take a $10 \mathrm{ppm}$ master solution using a pipette of 2, 5, 10 and $20 \mathrm{ml}$ and then put it in a $100 \mathrm{ml}$ measuring pumpkin. The solution that has been taken will be diluted by adding $\mathrm{HNO}_{3} 1 \mathrm{M}$ in the measuring pumpkin to the limit mark.

5. Lead Raw Curve Measurement

Four series of standard concentrations that have been created are then incorporated into the AAS tool, so that the absorbance value is obtained. This absorbance value is used to find the correlation coefficient value.

6. Analysis of Lead Metal Levels

The wet-instructed test sample was conducted measuring atomic uptake using an SSA with a wavelength of $283.3 \mathrm{~nm}$. The absorbance value obtained is then entered into the formula $y=$ $\mathrm{bx}+\mathrm{a}$ to obtain the concentration of lead levels.

\section{Finding and Discusion}

In the manufacture of activated carbon, randemen analysis, water content, ash content and absorption of iodine from hyacinths that have been dried and then carbonated with pyrolysis.

Result shown in Table 1 are known that the activated carbon of hyacinth has met water content quality test and iodine absorption test, but not yet fulfilled quality for ash test.

After the results of the active carbon quality test, qualitative tests were conducted on barito river water samples to find out the presence of lead heavy metal $(\mathrm{Pb})$ content using $\mathrm{HCl}, \mathrm{KI}$ and $\mathrm{NaOH}$ reagents. The results are presented in Table 2.

Result shown in Table 2 is known to be tested using the reagent $\mathrm{HCl}, \mathrm{KI}$ and $\mathrm{NaOH}$ found no content of lead heavy metal compounds in the Barito River.

Tabel 1. Results of Hyacinth Activated Carbon Analysis after Carbonization

\begin{tabular}{cccc}
\hline No & Analisis & SII No.0258-79 & $\%$ results \\
\hline 1 & Randemen & - & $15 \%$ \\
\hline 2 & Water Content & Max $10 \%$ & $3 \%$ \\
\hline 3 & Ash Rate & Max 2,5\% & $69 \%$ \\
\hline 4 & Iodine Absorption & Min $200 \mathrm{mg} / \operatorname{gram}(20 \%)$ & $241.16 \mathrm{mg} / \operatorname{gram}(24 \%)$ \\
\hline
\end{tabular}


After the results of quality tests, then conducted the administration of activated carbon hyacinth on barito river water samples with variations in the time of administration of 15 minutes, 30 minutes and 45 minutes to further measure the concentration of levels in each sample using Atomic Absorption Spectrophotometry (AAS).

Table 2. Results of Identification of Lead with Reagent $\mathrm{HCl}, \mathrm{KI}$ and $\mathrm{NaOH}$

\begin{tabular}{ccccc}
\hline No & Reagent & Result & Information & Picture \\
\hline & & & & \\
1 & $\mathrm{HCl}$ & Clear & Negative &
\end{tabular}

$2 \quad$ KI Clear
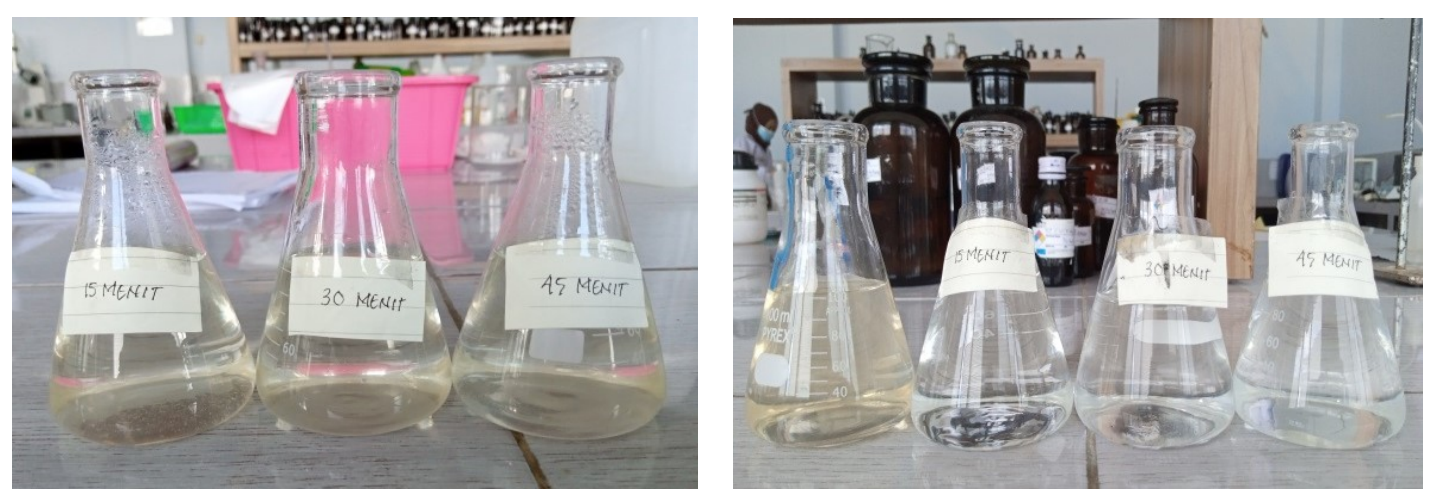

Figure 1. Barito River Water Samples Before and After Activated Carbon Hyacinth with Variations of Time Of 15 minutes, 30 minutes and 45 minutes.

Calibration curves are obtained by measuring the absorbance of some standard lead solution concentrations using atomic absorption spectrophotometry with a wavelength of $283.3 \mathrm{~nm}$. 
Table 3. Results of Measurement of the Absorbance of Lead Raw Solution

\begin{tabular}{ccc}
\hline No & Concentration $(\mathrm{ppm})$ & Absorbance \\
\hline 1 & 0 & 0,000 \\
\hline 2 & 0,25 & 0,010 \\
\hline 3 & 0,50 & 0,024 \\
\hline 4 & 1,0 & 0,046 \\
\hline 5 & 2,0 & 0,090 \\
\hline
\end{tabular}

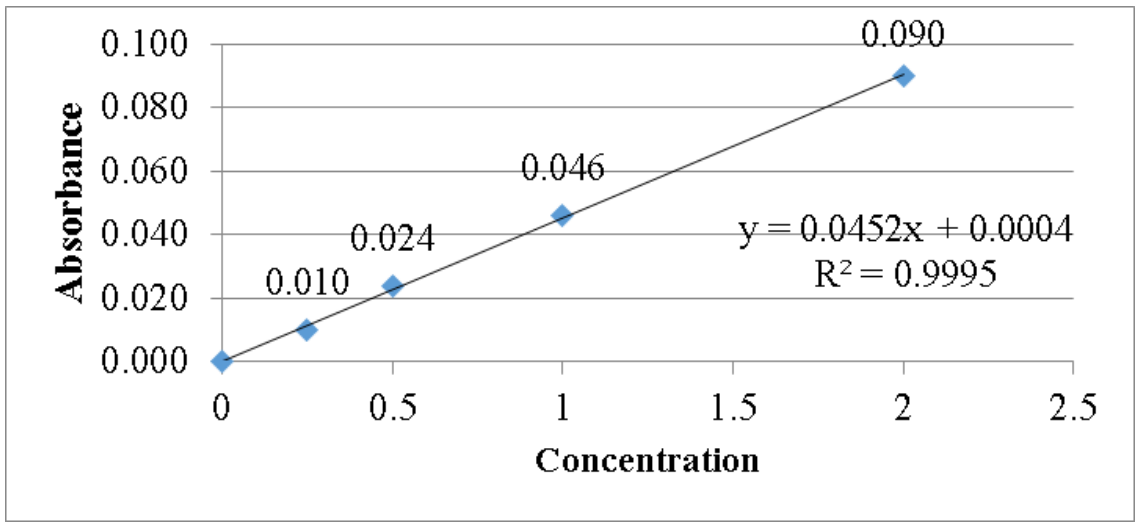

Figure 2. Raw Standard Lead Curve

Furthermore, the determination of the concentration of lead heavy metal $(\mathrm{Pb})$ levels in the Barito River water samples that have been contacted with the activated carbon of hyacinth.

Table 4. Measurement of Sample Concentration Values

\begin{tabular}{cccc}
\hline No & Time & Absorbance $(\mathrm{ppm})$ & Concentration $(\mathrm{mg} / \mathrm{L})$ \\
\hline 1 & 0 minutes & 0,0069 & 0,1430 \\
\hline 2 & 15 minutes & $-0,001$ & $-0,030$ \\
\hline 3 & 30 minutes & 0,0037 & 0,072 \\
\hline 4 & 45 minutes & $-0,004$ & $-0,097$ \\
\hline
\end{tabular}

Table 5. Results of Hyacinth Activated Carbon Adsorbtion Percentage

\begin{tabular}{ccc}
\hline No & Time & Absorption (\%) \\
\hline 1 & 15 minutes & $120 \%$ \\
\hline 2 & 30 minutes & $48 \%$ \\
\hline 3 & 45 minutes & $167 \%$ \\
\hline
\end{tabular}

Based on Table 5, maximum adsorbtion results of activated hyacinth activated hyacinth HCL occurs at a maximum contact time of 45 minutes of $167 \%$.

Some previous studies have stated that the content of lead heavy metals $(\mathrm{Pb})$ in the Barito River has high enough levels, triggering the emergence of various diseases caused by this heavy metal because most of the surrounding community utilizes the river water for daily needs. Therefore, a solution is needed to reduce the content of lead heavy metals $(\mathrm{Pb})$. One of them is by using activated carbon hyacinth. 
According to research conducted by Valentina et al in 2013 hyacinth plants contain $17.2 \%$ coarse protein, $15-18 \%$ fiber and $16-20 \%$ ash consisting of components potassium, calcium, carbon, sulfur and manganese. The main component of hyacinth is fiber in which contains cellulose groups by $60 \%$. Cellulose is high enough that can be used as a binder of metal materials so as to reduce the content of heavy metal lead $(\mathrm{Pb})[9]$.

The goal of the study was to create activated carbon derived from hyacinths by using $\mathrm{HCl}$ activators in accordance with SII No.0258-79 and find out the percentage of decreased levels of lead heavy metals $(\mathrm{Pb})$ in barito river water.

The manufacture of activated carbon from hyacinth is done with three stages, namely dehydration, carbonization and activation. The dehydration stage is done to remove water in the sample to be used. At this stage the removal of water on the sample by drying in the hot sun for a week. The carbonization stage aims to break down organic matter so that it becomes carbon. This carbonization process is done using furnance at a temperature of $600{ }^{\circ} \mathrm{C}$, the result of the carbonization process is characterized by the appearance of black and pungent air smoke.

The activation stage is carried out for tar decomposition and expansion of pores from activated carbon. Activating activated carbon can be done in two ways, namely through a weak oxidation reaction using water vapor at a temperature of $900-1,000^{\circ} \mathrm{C}$ or by dehydrating using chemicals or salts such as $\mathrm{CaCl}_{2}, \mathrm{ZnCl}_{2}, \mathrm{H}_{3} \mathrm{PO}_{4}, \mathrm{NaOH}, \mathrm{Na}_{2} \mathrm{SO}_{4}$ and others [10]. In this study chemical activation was done by adding $\mathrm{HCl} 1 \mathrm{M}$ to hyacinth charcoal. The reason $\mathrm{HCl}$ is used as an activator is because of the properties of $\mathrm{HCl}$ that can damage tissues in plants by removing metal oxides in charcoal that cover pores so as to enlarge pores when there is adrorpsi between adsorbate and adsorbens [11].

Quality tests are used to determine whether activated carbon meets established standards to be used as an absorbent in lowering lead levels in river water which includes randemen, water content, ash content and iodine absorption based on SII No.0258-79. The results of calculations and analysis showed that the quality of activated carbon still did not meet the quality standards, namely in the ash level quality test.

The randemen test is conducted to find out the amount of activated carbon produced after going through the authorship process. The maximum amount for randemen results is not specified in SII, but from table 1 shows that the resulting randemen is only $15 \%$ which means low value due to the size of the activated carbon raw material and the washing process. The size of the raw material is too small to allow charcoal to be lost in relatively large quantities because it produces ash, then at the time of the process of washing and filtering charcoal that is done repeatedly makes some of the activated carbon dissolved or wasted.

Water content determination tests are conducted with the aim of knowing the hygroscopic properties of activated carbon. High water content can reduce the quality of activated charcoal because it can reduce absorption to gases or liquids. From table 1 shows that the water content contained in hyacinth activated carbon is $3 \%$ which means the water content of activated hyacinth carbon produced has met the quality of activated carbon with a water content value that is far below the maximum water content limit used.

The purpose of determining the level of activated carbon ash is to determine the content of metal oxides in activated carbon. High ash levels can reduce the quality of activated carbon because the higher the ash content, the more inorganic material contained in the material. Table 1 shows that the results of the ash test are $69 \%$. This high ash content can be caused due to high temperatures. This is in accordance with the theory developed by Ikawati \& Melati in 2009 [12] that the higher the temperature of pyrolysis, the higher the ash level is increased because the increase in temperature can trigger the oxidizing of most volatile substances including carbon, while the ash is not oxidized because it is not a volatile substance.

The iodine absorption test aims to test the ability of activated carbon to absorb molecules that will be in contact with activated carbon. In this test used potassium dichromate as the primary standard and sodium thiosulfate as a secondary standard. From table 1 shows that the iodine absorption test produced is $241.16 \mathrm{mg}$ / gram or $24 \%$ which is the value of SII No.0258-79 with a minimum limit of $20 \%$ (200 mg / gram).

The identification of lead heavy metals with $\mathrm{HCl}$ reagent in Barito River water gives a clear color to the sample solution. According to Vogel's [13], samples containing lead heavy metals when reacted with an $\mathrm{HCl}$ solution will form insoluble white lead chloride or in the form of precipitates. The sediment will dissolve perfectly when heated in water that has a temperature of $100^{\circ} \mathrm{C}$. Based on the results of studies that have been done do not show white deposits, this can be interpreted that the content of lead heavy metals in the sample is low. 
The next result of the identification of lead heavy metals is using KI reagent. Samples reacted with a kl solution of 5 drops give a clear color to the sample solution. According to Vogel's [13], samples containing lead heavy metals when reacted with KI solution will form lead iodide that gives results in the form of yellow deposits. According to the 2014 Passion study, factors that can affect the nonformation of a yellow deposit if the sample is reacted with a KI solution, can be caused by the low content of a lead heavy metal compound in the sample, so that when tested is not identified.

The last identification using $\mathrm{NaOH}$ reagent. In the results of the study, barito river water samples after reacting with a solution of $\mathrm{NaOH}$ as much as 5 drops gave a clear color to the solution. According to Vogel's [13], samples containing lead heavy metals when reacted with $\mathrm{NaOH}$ solution will form lead hydroxide that gives color in the form of white deposits, but deposits will dissolve if added $\mathrm{NaOH}$ in excess. The results did not show the presence of lead heavy metal compounds in the sample.

Quantitative testing to measure lead metal $(\mathrm{Pb})$ levels in samples was conducted using Atomic Absorption Spectrophotometry (AAS) with a wavelength of $283.3 \mathrm{~nm}$. The result of measuring the absorbance value of the curve is obtained the correlation coefficient value (r) of 0.9995 which means it has met the conditions set by the SNI, namely the correlation coefficient value must be $\geq 0.995$. The absorbance value is then made a relationship curve between the concentration value ( $\mathrm{x}$ axis) and the absorbance (y axis) with the formula $\mathrm{y}=\mathrm{bx}+\mathrm{a}$ so that a straight line equation is obtained on the graph.

Results from the analysis of lead metal levels in Barito River water that has been added activated carbon using atomic absorption spectrophotometry can be seen in table 2 which shows that there is a difference in the content of lead heavy metals in river water with variations in the administration of activated carbon hyacinth at 15 minutes by $-0.030 \mathrm{mg} / 1$ with absorption of $120 \%, 30$ minutes by $0.072 \mathrm{mg} / 1$ with an absorption of $48 \%$ and 45 minutes of $-0.097 \mathrm{mg} / 1$ with an absorption of $167 \%$.

The maximum absorption achieved by activated carbon hyacinth is within 45 minutes with adsorption of $167 \%$. In the adsorption process with a contact time of 30 minutes indicates that the activated carbon has been saturated so that the adsorption is very low. However, because the bond that occurs between the surface of the activated carbon and the substrate is weak, this bond becomes detached again, so that the surface of the activated carbon that was previously bound to the substrate becomes empty.

The longer the contact time given to the activated carbon, the chance of the substrate to re-bond the greater so that the adsorption capacity of activated carbon again increases. This is in accordance with Suyata's statement [14] which states that adsorption events in activated carbon occur due to the Van Der Waals Force, i.e. the intertherolescular attraction between solid molecules and suspended solutes greater than the attraction force of the fellow solute itself in the solution, then the solute will be concentrated on the surface of the solid. This is supported by the statement of Notodarmojo [15] that the adsorption process in organic substances is physical adsorption and is dominated by Van Der Waals Style which has a weak bond so that it is reversible or can be detached again.

\section{Conclusion}

The results of research that has been done can be concluded that the activated carbon of hyacinth is still not able to be used optimally in the adsorption process because it does not meet the chemical characteristics to be used as an adsorbent because the resulting ash content is $69 \%$. But from this study it can also be concluded that the active carbon of hyacinth has the potential in lowering the content of lead heavy metals $(\mathrm{Pb})$ in river water with a maximum feeding time of 45 minutes which produces an absorption of $167 \%$.

\section{References}

[1] Rochgiyanti, "The Function of the River for the Community on the Banks of the Kuin River of Banjarmasin City," Community: International Journal of Indonesian Society and Culture, vol. 3, no. 1, pp. 51-59, 2013.

[2] N. Hikmah, "Analysis of Ammonia Levels (NH3) In the Waters Around the Rubber Plant Banjarmasin Area Using Visible Spectrophotometry," Thesis. Banjarmasin: Sari Mulia University, 2019.

[3] A. S. Sumayya, A. Zubair and R. Ibrahim, "Absorption Efficiency of Pb2+ Metal Using A Mixture of Bentonite and Hyacinth," USU Journal of Chemical Engineering, vol. 1, no. 1, pp. 1-8, 2015. 
[4] D. Sofarini, A. Rahman, and I. Ridwan, "The Study Analyzed Heavy Metal Testing on Bodies of Water, Biota and Sediment in The Estuarine Waters of The Barito Watershed," Bumi Lestari Journal of Environment, vol. 10, no. 1, pp. 28-37, 2011.

[5] D. A. Ningsih, I. Said, and P. Ningsih, "Adsorption of Lead Metal (Pb) From the Solution by Using Adsorbens From Corn Cobs," Journal of Academic Chemistry, vol. 5, no. 2, pp. 55, 2017.

[6] M. D. Tudjuka, D. K. Walanda and B. Hamzah, "Hyacinth Charcoal (Eichhornia Crassipes) As A Phenol Adsorben In Palu Power Plant Waste," Journal of Chemical Akedemika, vol. 6, no. 2, pp. 119-124, 2017.

[7] M. Bittremieux, R. M. La Rovere, H. Akl, C. Martines, K. Welkenhuyzen, K. Dubron, M. Baes, A. Janssens, P. Vandenberghe, L. Laurenti and K. Rietdorf, "Constitutive IP 3 Signaling Underlies The Sensitivity Of B-Cell Cancers To The Bcl-2/IP 3 Receptor Disruptor BIRD-2," Cell Death \& Differentiation, vol. 26, no. 3, pp. 531-547, 2019.

[8] T. I. Verhoef, W. K. Redekop, F. Hasrat, A. der Boer and A. H. M.-V. der Zee, "Cost Effectiveness of New Oral Anticoagulants for Stroke Prevention in Patients with Atrial Fibrillation in Two Different European Healthcare Settings," American Journal of Cardiovascular Drugs, vol. 14, no. 6, pp. 451-462, 2014.

[10] J. R. Sánchez-Pérez, C. Boztug, F. Chen, F. F. Sudradjat, D. M. Paskiewicz, R. B. Jacobson, M.G. Lagally and R. Paiella, "Direct-Bandgap Light-Emitting Germanium in Tensilely Strained Nanomembranes," Proceedings of the National Academy of Sciences, vol. 108, no. 47, pp.18893-18898, 2011.

[11] I.W. Kusuma, E. T. Arung, and Y. U. Kim, "Antimicrobial and Antioxidant Properties of Medicinal Plants Used by The Bentian Tribe from Indonesia," Food Science and Human Wellness, vol. 3, no. 3-4, pp. 191-196, 2014.

[12] Ikawati and Melati, Peran Teknik Kimia dalam Menjamin Ketahanan Pangan dan Energi Nasional. Jakarta: Seminar Nasional Teknik Kimia Indonesia, 2009.

[13] Vogel, Qualitative Inorganic Analysis Text Macro and Semimicro. Fifth edition. Jakarta: Kalman Media Library, 1985.

[14] I. Suyata, "Decreased Levels of Ammonia, Nitrite and Nitrate Liquid Waste Industry Tofu Uses Activated Charcoal from Coffee Grounds," Journal of Molecules, vol 4, no. 2, pp. 105-114, 2009.

[15] Q. Helmy, M. Zahra and S. Notodarmojo, "A Small Scale, Low Technology Water Treatment Plant: The Treatment of Raw Water with High Suspended Clay, Iron, and Manganese," in Conference proceedings of the 5th environmental technology and management, 2015. 